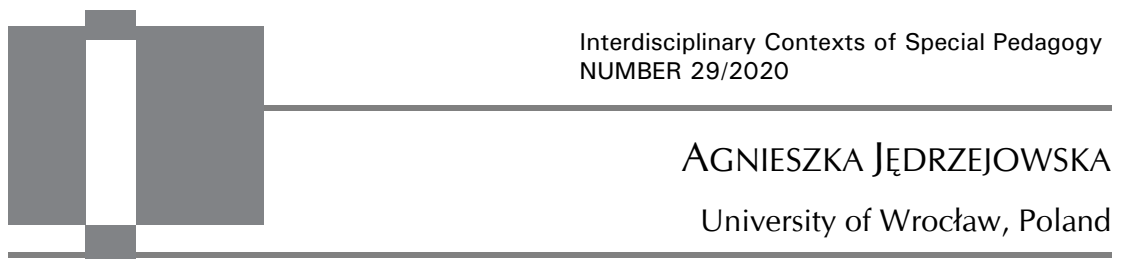

\title{
Developing social competences of children with Down syndrome by playing
}

\begin{abstract}
Agnieszka Jędrzejowska, Developing social competences of children with Down syndrome by playing. Interdisciplinary Contexts of Special Pedagogy, no. 29, Poznań 2020. Pp. 117-147. Adam Mickiewicz University Press. ISSN 2300-391X. e-ISSN 2658-283X. DOI: https:// doi.org/10.14746/ikps.2020.29.06

The subject of this article is a report from a study on the functioning of children with Down syndrome in a pre-school integration group and the rationality of attending kindergarten. During the research, children with Down syndrome in two groups in a kindergarten in Wrocław were observed. The research started with the thesis that play is the basic form of children's activity, in which, among others, the social competence of children is shaped. The activity most willingly chosen by children during free play were theatrical forms (role playing, puppet theatres, shadow theatres). The research was conducted for nine months; I was a researcher and educator in this kindergarten.
\end{abstract}

KEY WORDS: Social competence, fun

\section{Introduction}

Humanities pedagogy perceives the process of education as a dialogue. Dialogue is a method, process and attitude. "The dialogue method is a way of communication, in which subjects strive to understand each other, get closer and cooperate. The dialogue attitude is a readiness to open up to understanding, getting closer 
and cooperating in relation to the environment. Therefore, a dialogue attitude is an openness towards another human being" ${ }^{1}$

One of the key competences, important for the development of individuals and groups, is social competence. Competence is the potential that exists in a person. ${ }^{2}$ Maria Czerepaniak-Walczak believes that an individual's competence is its special characteristic, expressed in demonstrating, at the level set by social standards, the ability to behave adequately, as well as being aware of the need for and consequences of such conduct and in assuming responsibility for it. ${ }^{3}$ Katarzyna Koszewska defines this notion in a similar way, as a range of knowledge (I know about something), skills (I know how to do it) and responsibility (attitude - I want and am ready to use my knowledge); a range of powers and authority to act. Competence is a potential ability that becomes apparent when performing a given task or a predisposition to perform it. ${ }^{4}$ It is claimed that a socially competent person can generate effective communication strategies to maintain and develop interpersonal relationships. ${ }^{5}$

The notion of social competence is accompanied by such components as empathy, the ability to interact with others, both peers and adults, the ability to share one's possessions, as well as experiences and emotions, and a sensitivity to the harm of others and the desire to help. All these elements of social development are particularly shaped in the preschool period. The child first goes through a stage of egocentrism, therefore in the initial phase the relationship between peers is tense and there are often disputes and quarrels. Kindergarten is a good ground for shaping children's social compe-

${ }^{1}$ J. Tarnowski, Jak wychowywać?, Wydawnictwo ATK, Warszawa 1993, pp. 117-118.

${ }^{2}$ M. Armstrong. Zarządzanie zasobami ludzkimi, Oficyna Ekonomiczna, Kraków 2002, pp. 249-252.

${ }^{3}$ M. Czerepaniak-Walczak, Między dostosowaniem a zmiana, Szczecin 1995, p. 134.

${ }^{4} \mathrm{~K}$. Koszewska, Co to sa kompetencje społeczne?, Mazowiecki Kwartalnik Edukacyjny "Meritum”, 2014, no. 2(33), p. 2.

${ }^{5} \mathrm{~J}$. Lubowiecka, Kompetencje spoteczne w sytuacjach edukacyjnych $w$ przedszkolu, [in:] H. Sowińska (ed.), Dziecko w szkolnej rzeczywistości. Zatożony z rzeczywisty obraz edukacji elementarnej, Wydawnictwo UAM, Poznań 2011, p. 377. 
tences, as long as favourable conditions and appropriate stimulation of such behaviour are provided. ${ }^{6}$ The development of a child's self-image consists in the satisfaction with the relationship with his or her friends and his or her own position in the group, which influences the feeling of happiness and acceptance of self. This is the beginning of identity formation. According to Jerzy Nikitorowicz, the "significant Others", whose role is to set certain points of reference with which the child can identify, are necessary for its development. ${ }^{7}$

Social competence develops through experience which can take place in everyday life situations and in educational situations intentionally organized by the teacher. An ideal way to develop children's social skills is to work in groups. In a game or a task, group members communicate, negotiate, do something together, help each other, present the results of their actions, have fun together.

\section{The importance of play in diagnosing social skills}

The diagnosis of social skills requires an understanding of the situational parameters of behaviour, taking into account the factors that precede it and its consequences, as well as an awareness that different children's behaviours can be assessed in a different way. The difference of opinion about what behaviour is desirable or accepted in children and what is not, is due both to the reliability of the assessment and the way adults, who have different relationships with the child, peers and even the child itself perceive it. ${ }^{8}$

${ }^{6}$ A.I. Brzezińska, M. Mielcarek, A. Ratajczyk, Mali aktorzy na scenie życia, czyli o rozwoju kompetencji społecznych w okresie dzieciństwa, Mazowiecki Kwartalnik Edukacyjny „Meritum” 2014, no. 2(33), p. 19.

${ }^{7} \mathrm{~J}$. Andrzejewska, Zróżnicowanie modeli edukacyjnych w przedszkolu a funkcjonowanie psychospoteczne dzieci, Wydawnictwo Uniwersytetu Marii Curie-Skłodowskiej, Lublin 2013, p. 16.

${ }^{8}$ K. Kaszlińska, Diagnozowanie kompetencji społecznej dzieci przedszkolnych - możliwości i ograniczenia, „Przegląd Pedagogiczny” 2015, no. 1, p. 215. 
For the teacher, the main diagnostic area is when children begin playing. As Lew S. Wygotski and Danuta Waloszek emphasize, play is an attribute and the most important activity related to childhood. Observing children in their natural environment and during free behaviour is an excellent field for assessing the development of social skills in children. ${ }^{9}$

Play is an activity that comes from a natural need to learn about reality and action. Stuart Brown, psychiatrist, clinical researcher and founder of the National Institute for Play, describes from his own research and the discoveries of biologists, psychologists and neurologists how play helps to shape one's mind, empathy, allows to find oneself in a group, and is a source of creativity. ${ }^{10}$

Play is a characteristic, even fundamental, element of the behaviour of all children. It plays a significant role in their mental development. Howard Gardner presents the goals of play in the development of a child: "(...) a better mastery of the world, a more adequate handling of problems and fears, a better understanding of oneself and the relationship between oneself and the world, an initial discovery of the relationship between reality and fantasy, an area where intuitive, quasi-logical forms of thinking can be freely tested".11

For a child, the goal of play is pleasure itself, without any conscious goals. From a social point of view, the developmental sequence in a child's play can be indicated as follows ${ }^{12}$ :

- 18 months - 2 years - individual play with the use of various objects such as toys;

${ }^{9}$ K. Kaszlińska, Diagnozowanie kompetencji społecznej dzieci przedszkolnych - możliwości i ograniczenia, „Przegląd Pedagogiczny” 2015, no. 1, p. 218.

10 S. Brown, Ch. Vaughan, Play: How It Shapes the Brain, Opens the Imagination, and Invigorates the Soul, Pinguin Group, Nowy Jork 2009.

11 A. Birch, T. Malim, transl. by. J. Łuczyński, M. Olejnik, Psychologia rozwojowa $w$ zarysie. Od niemowlęctwa do dorostości, Wydawnictwo Naukowe PWN, Warszawa 1995, p. 29.

12 A. Birch, T. Malim, transl. by. J. Łuczyński, M. Olejnik, Psychologia rozwojowa $w$ zarysie. Od niemowlęctwa do dorosłości, Wydawnictwo Naukowe PWN, Warszawa 1995 , p. 30. 
- 3 years of age - children play next to each other, sometimes this is accompanied by observation and mutual imitation, but still without real interactions;

- about 4 years of age - play becomes socialized, interactions appear - at first rigid, but then turn-taking which means means complementary behaviour and cooperation.

Jean Piaget links the development of play with the development of intelligence and concludes that it is possible to partially assess the development of a child on the basis of observation of the way he/she plays. He suggests the following stages of playful activity:

- Sensory-motor play corresponds to the sensory-motor level of intelligence development (from birth to the end of the second year of life). Various objects are examined by sight and touch, the movements are repeated.

- Symbolic play appears at the preoperative level of intelligence development (between the second and seventh year of life). The child uses his/her imagination and is satisfied with using one object as a symbol of another object (e.g. a tennis racket can become a guitar).

- Role play is appropriate for the operational level of intelligence development (from the age of seven). The child's developing thought processes become more logical, and when playing, the child uses various procedures and rules.

J. Piaget claims that play is an expression of the assimilation process, in which the child tries to incorporate knowledge about the world surrounding him or her, adjusting it to his or her experience and understanding of the world. ${ }^{13}$ On the other hand, Jerome S. Bruner sees play as an opportunity to learn, develop motor and cognitive skills. Lew S. Wygotski also stresses the value of play as the main developmental factor. It is play that creates a zone of closest development, where the child can act at a higher level of development than that intended for his or her age. One of the ways to

${ }^{13}$ A. Birch, T. Malim, transl. by J. Łuczyński, M. Olejnik, Psychologia rozwojowa w zarysie. Od niemowlęctwa do dorostości, Wydawnictwo Naukowe PWN, Warszawa 1995 , p. 31. 
assess a child's possible development at a given moment is to determine the distance between the level of activity achieved through play and activity in other everyday situations.

Sigmund Freud in his psychodynamic theory of development treats play as a means of lowering the level of suppressed emotions. Play can be used by children to explore and deal with their feelings and to work out their fears and anxieties in a safe situation. Play can therefore be treated as a defence against problems, as well as dealing with them.

Eric Erikson believes that "children's play is an infantile form of the human ability to cope with one's experiences by creating model situations and improving reality through experimentation and planning". ${ }^{14}$ Playful activity supports physical, intellectual and social fitness. ${ }^{15}$ Playing in a peer group is a source of different stimuli, e.g. unforeseen behaviour of the participants, their successful and unsuccessful attempts at communication, conflict resolution, searching for new and interesting objects. At the same time, the complex social situation forces the participants to use their minds, creating unforeseen events that require immediate decisions and make an effort to understand what is happening. ${ }^{16}$

At first, children tend to play alone. This is due to the fact that although the child formally belongs to a preschool group, the most important person for him/her is the teacher who satisfies his/her basic needs. ${ }^{17}$ When a child plays alone, he/she plays with other toys, regardless of other children, sometimes talks to other children, but does not make contact with them regarding play activities. In-

14 A. Birch, T. Malim, transl. by J. Łuczyński, M. Olejnik, Psychologia rozwojowa w zarysie. Od niemowlęctwa do dorostości, Wydawnictwo Naukowe PWN, Warszawa 1995 , p. 32.

${ }^{15} \mathrm{H}$. Olechnowicz, Terapia dzieci z niepetnosprawnościa intelektualna, Wydawnictwo Naukowe PWN, Warszawa 2010, p. 255.

16 H. Olechnowicz, Terapia dzieci z niepetnosprawnościa intelektualna, Wydawnictwo Naukowe PWN, Warszawa 2010, p. 259.

17 B. Tylewska-Nowak, Wiek przedszkolny - pomiędzy wyobcowaniem a grupq rówieśnicza, [in:] H. Kubiak, A. Jakoniuk-Diallo (ed.), Człowiek niepetnosprawny w otoczeniu społecznym, Wydawnictwo Difin SA, Warszawa 2011, p. 57. 
dividual games turn into parallel games when children play side by side, when they play alone but often with the same toys. During such games, children build a tower of blocks, but they do not cooperate with each other and each builds their own. The next step in the development of a child's playful activity is to play together, when children exchange toys and talk about the activities. However, such form play is not planned and there is no role-playing. Over time, the child moves on to team games, with role-playing. Children form teams for the purpose of playing, sometimes one or two children organize a game for the others. For example they play home, at the shop, at the doctor's, kindergarten. During these games, children share their roles, agree on who will be who and what they will do.

When a child plays with his or her peers or other companions, they learn the rules of cooperation. When role-playing, each participant has to take a different point of view of reality than his or her own in order to fulfil the intended plan and reproduce a relevant behaviour and features of the character. It is important to realize that the game will be beneficial if each participant takes into account their own preferences for their character. Such a situation is an ideal opportunity for the child to understand and acquire particular social skills. It starts with expressing one's will and needs openly and clearly, through contacting other participants, listening to other children, understanding their intentions, the need to resolve conflicts and disputes, recognizing the existing contradictions, and dealing with strong emotions. This aspect is extremely important in diagnosing the ways of communication and the level of socialization of children in kindergarten. ${ }^{18}$

Kindergarten is an ideal place to learn the rules of social life, play is an activity that introduces all these rules in a natural way for the child. In peer relations, children feel the interaction on an equal level, it is the basis for establishing social contacts. All these beha-

18 A.I. Brzezińska, M. Bątkowski, D. Kaczmarska, A. Włodarczyk, N. Zamęcka, O roli zabawy w przygotowaniu dziecka do dorostego życia. Wychowanie w Przedszkolu, 2011, no. 10, p. 8 . 
viours are based on developmental norms and stages of mental maturation. ${ }^{19}$

Social competence is combined with communicative competence, i.e. the use of verbal and/or non-verbal behaviour in a manner appropriate to the context. It is the ability to assess the relevance and effectiveness of a person communicating or the goal achieved by communication. A specific behaviour may be appropriate and effective in one context, but not in another. The communication process depends on the motivation, knowledge and ability of the individuals involved and the context of interaction. ${ }^{20}$

Children who fail to master social skills, including cooperative skills, are more likely to get angry, and their clumsiness and anxiety can make others feel uncomfortable in their company. The resulting negative experiences in social relationships can cause low self-esteem and hinder learning. In adulthood, they may face depression and constant anxiety, and in extreme cases, this kind of social inadequacy may even lead to complete social rejection ${ }^{21}$. Children with developmental disabilities are particularly at risk. Teaching social skills, including cooperation skills will allow to avoid the consequences of social rejection and achieve predispositions to find oneself in a world that requires constant adaptation to change. ${ }^{22}$

Already at the age of two and three, pro-social behaviour, also known as altruistic behaviour, can for the first time be observed in children. A three-year-old child starts showing interest in playing with other children. He/she will offer help to the child who has

${ }^{19}$ E. Miśkowiec, Ksztattowanie umiejętności kontaktów społecznych dziecka w rodzinie i przedszkolu, „Edukacja Elementarna w Teorii i Praktyce” 2006, no. 25/3, p. 27.

20 S.P. Morreale, B.H. Spitzberg, J.K Barge, Komunikacja między ludźmi. Motywacja, wiedza i umiejętności, transl. by D. Kobylińska, P. Izdebski, A. Jaworska, Warszawa 2007, p. 22.

${ }^{21}$ M. Plummer, Jak ksztattować umiejętności społeczne. Gry i zabawy grupowe dla dzieci od lat pięciu do jedenastu, Wydawnictwo Fraszka Edukacyjna, Warszawa 2010, p. 24.

22 D.M. Plummer, Jak kształtować umiejętności społeczne. Gry i zabawy grupowe dla dzieci od lat pięciu do jedenastu, Wydawnictwo Fraszka Edukacyjna, Warszawa 2010, p. 24. 
been injured, propose a toy or try to comfort him. ${ }^{23}$ At this age children begin to understand that the people around them can feel something different from themselves. Friendships begin to form. The first manifestations can already be seen around the eighteenth month. Toddlers become more willing to be surrounded by particular children. Preschool-age friends are nicer to each other, interact with each other more often, and show more positive and less negative behaviour. They also show more support in new situations. Friendships at this age are usually formed between children of the same sex. Even among young children, two and three year olds, most relationships are mono-sexual and remain so until the start of school, when children start choosing friends on the basis of common interests and gender often does not matter. ${ }^{24}$

Children with Down syndrome tend to engage in parallel individual play (they play alongside other children, but do not interact). In such situations, the role of a mediator (intermediary) is very valuable, someone who leads the child into a more structured play that requires contact with other children and accompanies the child during playtime. This mediation can consist of physical guidance, shaping circumstances, forming relationships in a group so that the child is better integrated, giving responsibility for changes by asking questions such as "who is to be who in this game?". ${ }^{25}$

Anna Sobolewska, the mother of now adult Celia who has Down syndrome, writes about the loneliness of children and youth in educational institutions:

Our children do not have their own environment. And this is the dark side of their life and ours. The biggest concern is the lack of real part-

${ }^{23}$ H. Bee, Psychologia rozwoju człowieka, Wydawnictwo Zysk i S-ka, Poznań 2004, pp. 234-240.

${ }^{24}$ H. Bee, Psychologia rozwoju cztowieka, Wydawnictwo Zysk i S-ka, Poznań 2004, pp. 240-241.

${ }^{25}$ E. Zausmer, Zabawy i umiejętności manualne, [in:] S.M. Pueschel (ed.), Ku lepszej przyszłości. Zespót Downa. Przewodnik dla rodziców i opiekunów, Wydawnictwo Replika, Zakrzewo 2009, pp. 195-196. 
nership in contacts with other children. This is especially painful during the holidays. We want our children to have friends or acquaintances. ${ }^{26}$

Children who have no friends and are not very popular experience a sense of worthlessness or incompatibility.

Further, Prinstein's and La-Greca's studies show that the feeling of loneliness grows even more in adolescence, when the emotional bond with parents is clearly weakened, and at the same time the isolation of these people in school increases. ${ }^{27}$ Such experiences are important for shaping the personal and social identity of each person. This is confirmed by the Polish research conducted by Agnieszka Żyta; she conducted interviews with adults with Down syndrome. They differ in their awareness and acceptance of their otherness. 28

M. Margalit came to the conclusion that the social isolation of people with intellectual disabilities is determined by a lower level of school achievement, underdeveloped social skills, taking on the social role of a person with disabilities, excessive concentration on the Self. ${ }^{29}$ So how can a person with intellectual disabilities realise themselves? At this point it is worth recalling the Kurt Goldstein personality theory. Intellectual deficit and impaired cognitive functions are not an obstacle in the process of self-realization. The difficulty may be the dependence of a person with disabilities on others without whom he/she will not realize this need. The neurologist and psychiatrist defines this phenomenon as reaching an agreement with the environment. ${ }^{30} \mathrm{~K}$. Goldstein is not interested in the theory of

${ }^{26}$ A. Sobolewska, Cela, Wydawnictwo W.A.B., Warszawa 2002, p. 203.

27 S. Kowalik, Psychologia niepetnosprawności umystowej. Psychologia niepetnosprawności umystowej, [in:] H. Sęk (ed.), Psychologia kliniczna, Vol. 2, Wyd. Naukowe PWN, Warszawa 2005, p. 154.

28 A. Żyta, Życie z zespołem Downa. Narracja biograficzne rodziców, rodzeństwa i dorostych osób z zespołem Downa, Oficyna Wydawnicza „Impuls”, Kraków 2011, p. 216.

29 S. Kowalik, Psychologia niepetnosprawności umystowej, [in:] H. Sęk (ed.), Psychologia kliniczna, Vol. 2, Wydawnictwo Naukowe PWN, Warszawa 2005, p. 154.

30 C.S. Hall, G. Lindzey, G.B. Cambell, Teorie osobowości, PWN, Warszawa 2004, pp. 432-435. 
learning. However, he indicates the serious consequences of the difficult conditions of a given environment for a child, which may result in the lack of possibility of self-fulfilment and further development of pathological processes. ${ }^{31}$

The analysis of the subject carried out by D. Gibson, which is referred to by E. Zasępa, was of great importance for research on social development of children with Down syndrome ${ }^{32}$. He established the following relationships between the social maturity quotient and the intelligence quotient:

- the social maturity age of people with mental disabilities caused by other reasons is higher than in the case of people with Down syndrome who are of the same intelligence age;

- the social maturity age is on average 3 years and 4 months higher than the age of intelligence;

- the social maturity age progresses regardless of the age of intelligence, together with the age of life, especially in the early years.

C. Cunningham reports that the age of social maturity in children with Down syndrome is usually 3 years higher than their intelligence age. The reason may lie in the tasks that are included in the scale for measuring social maturity. These are tasks that measure the independence of activities that are taught at home every day and are absorbed by children more easily than tasks that measure language or mental abilities, which are more dependent on psychophysical abilities. The researcher further concludes that the results of tests measuring mental capacity, speech development and social functioning are highly correlated with each other. A child with higher mental function has more developed social and language skills. In most cases, social development is relatively the highest and

31 D. Baczała, Metoda Knillów a teoria osobowości Kurta Goldsteina (studium indywidualnego przypadku), [in:] Z. Gajdzica (ed.), Wspólne i swoiste zagadnienia edukacji i rehabilitacji osób z upośledzeniem umysłowym, Wyd. Humanista, Sosnowiec 2008, pp. 119-121.

32 E. Zasępa, Rozwój intelektualny dzieci z zespołem Downa, Wydawnictwo Akademii Pedagogiki Specjalnej im. Marii Grzegorzewskiej, Warszawa 2003, p. 38. 
the age denoting speech development is the lowest. Development of speech is more difficult than learning self-service activities. ${ }^{33}$

In order to describe the social development of young children with Down syndrome one should take into account that it is a resultant of intellectual capabilities, development of perception and cognitive processes, motor skills and mind theory. The social development of a child with DS can be perceived from different perspectives. It is possible to refer the social development of a child with DS to the development of a healthy child, to compare children with DS to the development of children with another etiology of intellectual disability and finally to look at the progress of social development of a child with DS in the context of other spheres of its development.

In order to support the social development of a child in a peer group, it is necessary to realize what deficiencies in social development hinder his/her functioning in this group. Research conducted by Ludwika Sadowska and her colleagues ${ }^{34}$, evaluating the effects of the therapy of young children with DS with the use of the Munich Functional Developmental Diagnostics, has shown improvement in psychomotor functions, especially in terms of muscle tension, coordination and efficiency of the articulatory apparatus, whereas the sphere of spontaneous activity and intellectual achievements improved the least.

The research carried out by Anna Maria Choińska ${ }^{35}$ shows that the level of social development of children with DS up to the age of

${ }^{33}$ C. Cunningham, Dzieci z zespotem Downa. Poradnik dla rodziców, WSiP, Warszawa 1992, pp. 216-217.

${ }^{34}$ A. Białas, Rodzina a problemy rozwoju, wychowania i socjalizacji dzieci i młodzieży niepetnosprawnej, [in:] J. Patkiewicz (ed.), Udziat rodziny w kompleksowej rehabilitacji i życiu dzieci i młodzieży niepetnosprawnej, Polskie Towarzystwo Walki z Kalectwem, Wrocław 1999, pp. 73-83.

${ }^{35}$ A.M. Choińska, Zmiany w poziomie rozwoju fizycznego i sprawności psychomotorycznej dzieci z zespotem Downa od 0 do 3 roku życia, kompleksowo rehabilitowanych wedtug Wroctawskiego modelu Usprawniania. Doctoral thesis written under the direction of prof. dr hab. Ludwika Sadowska, Akademia Wychowania Fizycznego, Wrocław 2002. 
3 is comparable to the results of research carried out by Bożena Bartosik and colleagues ${ }^{36}$, L. Sadowska and colleagues ${ }^{37}$ and shows that the examined 3-year-olds were able to solve $56-77 \%$ of the tasks provided for a healthy 3-year-old in the following areas: statomotorics, grasping, perception, active speech and its understanding and social maturity and independence. Similar results of the relationship between communication skills and the age of initiation of therapy were obtained by Teresa Kaczan ${ }^{38}$ in the case of children with DS. The researcher showed that the progress in the development of grasping skills corresponded with the progress in the development of active speech and its understanding. The author also indicates that children with DS undergoing speech therapy had no major difficulties in contacting other people and were able to comply with the rules and regulations. They strived to establish contact and were spontaneous.

The results of these studies correspond to the studies carried out in an integration kindergarten by M. Niklasińska. ${ }^{39}$ The aim of the research was the perception of preschoolers with disabilities by their peers without disabilities. It turned out that when dealing with disabled children, healthy children take little account of their intellectual capabilities or external appearance. The readiness to play together,

${ }^{36}$ B. Bartosik, L. Sadowska, A. Kreft, Postęp w rozwoju spotecznym matych dzieci $z$ zespołem Downa poddanych terapii wedtug Wroctawskiego Modelu Usprawniania (WMU), [in:] J. Patkiewicz (ed.), Wspomaganie rozwoju dzieci z trudnościami w uczeniu się, Polskie Towarzystwo Walki z Kalectwem, Wrocław 2004, pp. 69-85.

${ }^{37}$ L. Sadowska, B. Bartosik, Uspołecznianie dzieci z zespotem Downa jako proces pokonywania barier społecznych, [in:] J. Patkiewicz (ed.), Problemy barier rozwoju dzieci i młodzieży niepetnosprawnej, Polskie Towarzystwo Walki z Kalectwem, Wrocław 2004, pp. 165-174.

${ }^{38}$ T. Kaczan, Wplyw wczesnej rehabilitacji mowy na rozwój umiejętności komunikacyjnych $i$ jezykowych u dzieci $z$ ZD. Doctoral thesis written under the direction of prof. dr hab. S. Maria Pecyna, Wyższa Szkoła Pedagogiki Specjalnej, Warszawa 2001.

${ }^{39}$ B. Bartosik, L. Sadowska, A.M. Choińska, Dojrzałość społeczna dzieci z zespotem Downa rehabilitowanych zgodnie $z$ zasadami Wroctawskiego Modelu Usprawniania w środowisku rodzinnym, [in:] J. Patkiewicz (ed.), Zespót Downa - postępy w leczeniu, rehabilitacji i edukacji, Polskie Towarzystwo Walki z Kalectwem, Wrocław 2008, pp. 106-107. 
the readability of social messages and the manifestation of emotions were taken into account in the first place. Children with DS were not perceived as disabled by healthy children and their readiness to syntonise and specific emotional viscosity made healthy children willing to take care of them and help them. Children with minimal cerebral dysfunction or autism spectrum disorders were perceived differently. Due to the low predictability of their behaviour, changeability, weirdness, they were not chosen as partners to play and functioned at the side of the group. Analysing the results of other research showing the differences in social development of children with DS in comparison to children with different etiology of intellectual disability, it can be assumed that the more beneficial social development of a child with DS is to some extent connected with a better development of the theory of mind. In the experimental research, which aimed to determine the level of development of the theory of mind, most of the examined children with DS, as compared to children with autism over the age of four, were able to perform the Unexpected Change Test correctly, therefore it can be concluded that these children, despite their lower intellectual level, are ready to feel the mental state of another person, and thus it can also be concluded that they have a better possibility for empathy and reading non-verbal messages. ${ }^{40}$ Also the results of previous research, conducted by J. Kruk-Lasocka ${ }^{41}$, in which the author related the social development of children with DS to children with cerebral palsy, show a higher level of social development in the case of children with DS. The author pointed out that the source of a better social functioning of children with DS is their readiness to imitate, perceptiveness, good mechanical memory, syntony. Children show love, affection and friendship to those who are kind, caring and gentle to them. On the other hand, they reject

40 B. Winczura, Diagnoza i terapia deficytów poznawczych dziecka autystycznego na podstawie koncepcji teorii umystu, [in:] B. Cytowska, B. Winczura (ed.), Dziecko z zaburzeniami w rozwoju. Konteksty diagnostyczne i terapeutyczne, Oficyna Wyd. IMPULS, Kraków 2005, pp. 65-93.

${ }^{41}$ B. Bartosik, L. Sadowska, A.M. Choińska, Dojrzałość społeczna dzieci z zespołem Downa..., op. cit., p. 107. 
people whose facial expressions and body language do not arouse conviction and trust. B. Bartosik, L. Sadowska, A.M. Choinska refer to many studies that describe the emotional and social development of children with DS42: research conducted on infants with DS showed less involvement in social situations and focus on fewer social stimuli as compared to infants with normal intellectual development. Studies of older children with DS around the age of 4 and other disabled peers without DS and healthy children of the same mental age showed that the level of development of the ability to recognize emotions is the same in the three groups of examined children Further on, the authors refer to the research of Elżbieta Maria Minczakiewicz, who in her study emphasizes the importance of using the syntonic abilities of children with DS when engaging them in an increasingly rich emotional and verbal dialogue. Joanna Kruk-Lasocka observes that even small children with DS, thanks to their warmth, love and gratitude for tenderness and care, were able to break the distance and rejection on the part of their parents and evoke an attitude of acceptance in them. ${ }^{43}$ For comparison, the lack of emotional syntony, interest in the mother, rejection of her caresses and inability to empathize can cause trauma in the mother, according to Aleksandra Maciarz.

Although the age of social maturity rises, a child with DS will never reach full emotional maturity. Emotional maturity (expressing, recognizing, controlling emotions) is connected with thinking, and this in the case of children with DS is delayed. This in turn will translate into limited possibilities of social functioning. It may be concluded that such a child will recognize simple, clear and legible social situations and function relatively well in them. On the other hand, wherever understanding of the social situation depends on reading more complex messages requiring abstract thinking and not connected with the child's experiences, children with DS will have difficulties.

Peers without disabilities provide a good opportunity for the development and happy functioning of such children and their

42 Ibid., pp. 107-108.

43 B. Bartosik, L. Sadowska, A.M. Choińska, Dojrzałość społeczna dzieci z zespołem Downa..., op. cit., pp. 107-108. 
families. Children without disabilities at preschool age are able to establish cooperation with a peer they did not know before. They are able to adapt their actions to the partner's actions and teach them new skills. Research by Andrzej Twardowski ${ }^{44}$ on communicative dialogue competence of preschool children without disabilities has shown that already four-year-olds apply elaborate strategies which make it easier for a less competent partner to participate in the conversation. For example, they ask questions which contain the information necessary to provide an answer, they give readymade answers and ask for their repetition or use additional instructions enriched with non-verbal elements. Already at preschool age, children without disabilities can adapt their behaviour and speech to the cognitive and linguistic abilities of their peers with intellecttual disabilities, e.g. they reduce the complexity of the game and try to make it more structured and readable for the partner. When speaking to their disabled peers, they use shorter, less grammatically complex statements consisting of words with a specific meaning. They try to articulate words clearly and repeat certain statements. The relationships between a child with a disability and their non-disabled peer are characterized by reciprocal influence. Both partners decide whether a relationship will be initiated and how it will proceed. Usually the interaction only takes place because a non-disabled child can understand the unclear statements made by a colleague with disabilities and correctly identify the intentions.

Interactions with peers support mental development. As C.R. Cooper has shown ${ }^{45}$, the very presence of peers has a mobilizing effect on the cognitive activity of preschool children. In the

44 A. Twardowski, Rola petnosprawnych rówieśników w procesie wspomagania rozwoju dzieci niepetnosprawnych, [in:] W. Dykcik, A. Twardowski (ed.), Wspomaganie rozwoju $i$ rehabilitacja dzieci z genetycznie uwarunkowanymi zespołami zaburzeń, Wyd. Naukowe Polskiego Towarzystwa Pedagogicznego, Poznań 2004, p. 83.

45 A. Twardowski, Rola petnosprawnych rówieśników w procesie wspomagania rozwoju dzieci niepetnosprawnych, [in:] W. Dykcik, A. Twardowski (ed.), Wspomaganie rozwoju $i$ rehabilitacja dzieci $z$ genetycznie uwarunkowanymi zespołami zaburzeń, Wyd. Naukowe Polskiego Towarzystwa Pedagogicznego, Poznań 2004, p. 83. 
presence of peers, children solve tasks better and faster than when they have to solve them alone.

A. Twardowski ${ }^{46}$ distinguishes two types of childhood interactions of an educational nature: peer tutoring and cooperative learning. The first one can be observed when one child (tutor) helps the other (novice) to master certain knowledge and skills by giving him/her guidance, instructions or directing his/her activities. The rationale for this type of learning is contained in L. Wygotski's concept, who believes that the development of a child can take place in relations with those who know more about culturally accepted practices and tools (he considers language the most important). All skills and knowledge are acquired in social experience and then internalized and decontextualised. 47

The term peer tutoring describes a symmetrical relationship, as the partners have a similar knowledge and skills base. But this resource is insufficient for each of them to solve the task on their own. Cooperation through the exchange of information, mutual explanations, discussions, and asking questions is the only condition for solving the task. This type of interaction is justified by J. Piaget's theory, who stated that peer contacts in the pre-operative period stimulate overcoming of egocentrism as they require children to compare their cognitive perspectives. The child is forced to decentralize because he or she has to coordinate his or her point of view with the cognitive perspective of the partners. The current representation of the child is restructured. As a result, the child acquires new knowledge - one which he or she would not have acquired in the course of activities performed alone. ${ }^{48}$

\section{Theatrical games}

Children's play can take different forms. Role-playing is one of the fun activities that plays a fundamental role in the diagnostic and

\footnotetext{
46 A. Twardowski, Rola petnosprawnych rówieśników..., op. cit., p. 83.

47 L.S. Wygotski, Wybrane prace psychologiczne, PWN, Warszawa 1971, p. 544.

48 A. Twardowski, Rola petnosprawnych rówieśników..., op. cit., pp. 84-85.
} 
therapeutic dimension. Małgorzata Taraszkiewicz describes this activity as a theatrical form (together with drama and simulation). According to the Author, role-playing is understood as behaviour depending on the place where a given person is or depending on the person that accompanies tchem. ${ }^{49}$ The child has an opportunity to work out the social roles that are a part of it, and therefore gains experiences that give rise to confidence. This in turn means that he/she gains the option to look at his or her actions and make beneficial changes. On the other hand, playing a role other than that known to the child from autopsy - such as a fictional, symbolic figure - makes this method a source of knowledge of the outside world. ${ }^{50}$ The child is given the opportunity to experience certain problems and find a solution for them. The simulations are based on a similar assumption - a child can practice certain skills or attitudes in a safe situation and face the consequences, because even if he makes a mistake, he can still fix it by playing his role again. This method involves training specific skills. This experience can be a source of a great sense of causality, subjectivity and control over one's life. It is important for the child to feel natural in a given situation, be aware of the reality, as it will train certain life skills, abilities such as confidence or effective communication..$^{51}$ Theatrical forms can shape emotional life and imagination, broaden horizons, build bridges of understanding, contacts, communities, satisfy and educate the needs of expression". 52

Regardless of the context of any of the methods proposed by M. Taraszkiewicz, the most important is the goal of the educational

${ }^{49}$ M. Taraszkiewicz, Jak uczyć lepiej - czyli refleksyjny praktyk w działaniu, Wydawnictwa CODN, Warszawa, 2000, p. 120.

${ }^{50}$ M. Taraszkiewicz, Jak uczyć lepiej - czyli refleksyjny praktyk w dziataniu, Wydawnictwa CODN, Warszawa, 2000, p. 121.

${ }^{51}$ M. Taraszkiewicz, Jak uczyć lepiej - czyli refleksyjny praktyk w działaniu, Wydawnictwa CODN, Warszawa, 2000, p. 128.

52 H. Guzy-Steinke, T. Wilk, Uczeń i teatr. Realia a poszukiwania możliwości realizacji edukacji teatralnej w szkole, Wydawnictwo Edukacyjne, "Akapit”, Torun 2009, p. 69. 
activity - i.e. the comprehensive development of the child's personality. A pedagogue should be interested in stimulating the child's imagination and empathy, developing his/her self-expression skills, shaping positive communication attitudes in conflict situations. ${ }^{53}$ Each activation method is designed to provide the participant with a spiritually uplifting experience, offering solutions to a variety of problems in a safe environment. Even the sudden turns of action or the logical consequences of decisions made by a child does not pose a threat, as long as the teacher creates a positive atmosphere in the common education experience. By allowing for constructive criticism and expression of one's own feelings and observations in an atmosphere of understanding and support, the teacher gives the less daring students a chance to develop something much more important - the feeling that they can express themselves in a favourable environment in which they will gain acceptance.

Romana Miller writes about the important role of theatrical forms for the development of a small child. Children from the age of three can better understand the world around them and themselves through these forms of influence, which can significantly influence their personality development. 54 The scientist also stipulates that for these purposes it is difficult to find a better form of influence. Another pedagogue, W. Renikowa, emphasizes that upbringing through theatre is the best way to the most complete development of the personality of pupils". ${ }^{55}$ Maria Dudzikowa also advocates preparing the child from the first stage of education to "selfdetermination, which is made in and through creation" and recommends that this approach be continued in further stages of edu-

${ }^{53}$ I. Borecka, Drama w programach edukacyjnych, wychowawczych i terapeutycznych, [in:] I. Borecka, M. Widerowska i in., Drama i arteterapia w szkole. Programy i scenariusze zajęć, Wydawnictwo Państwowej Wyższej Szkoły Zawodowej im. Angelusa Silesiusa, Wałbrzych 2005, pp. 20-22.

${ }^{54}$ H. Guzy-Steinke, T. Wilk, Uczeń $i$ teatr. Realia a poszukiwania możliwości realizacji edukacji teatralnej w szkole, Wydawnictwo Edukacyjne, „Akapit”, Torun 2009, p. 68.

${ }^{55}$ H. Guzy-Steinke, T. Wilk, Uczeń $i$ teatr. Realia a poszukiwania możliwości realizacji edukacji teatralnej w szkole, Wydawnictwo Edukacyjne, „Akapit”, Toruń 2009, p. 71. 
cation. The author goes on to write that in participatory education it is important to give the pupil an opportunity to play as many roles as possible so that he or she can experience many different points of view $^{56}$. The child, as an actor, expresses himself through playing. "An actor-creator is a creator who, in intentionally composed theatrical actions, through acting, publicly expresses his/her personality, reveals his/her world of values and spirituality, communicates his/her beliefs, desires, aspirations to others" 57 .

\section{Methodological assumptions of the research}

\section{Organization and research area}

From September 2009, a pilot project of inclusive education for children with Down syndrome in preschool education was implemented in Wroclaw. The project was initiated by parents from the Lower Silesian Association for People with Down Syndrome "Razem". From 2010 the project has been approved as a systemic solution (3-5 children with homogeneous disabilities - Down syndrome - attend the group). The implementation of the inclusive education program in selected Wrocław facilities was a result of information on the previous difficult educational paths for children with Down syndrome in integration facilities.

Also, research on the possibilities of children with developmental disabilities and ad hoc observations of the functioning of such children in peer relations led to the conclusion that the social skills of children with disorders were developed by imitating the behaviour of their peers. ${ }^{58}$

${ }_{56}$ H. Guzy-Steinke, T. Wilk, Uczeń i teatr. Realia a poszukiwania możliwości realizacji edukacji teatralnej w szkole, Wydawnictwo Edukacyjne "Akapit”, Torun 2009, p. 66.

57 A. Włoch, K. Maćkowiak, Pedagogiczne aspekty procesu kreowania postaci scenicznej w teatrze, Wydawnictwo Uniwersytetu Opolskiego, Opole 2016, p. 55.

58 A. Jędrzejowska, Stymulacja zaburzonych funkcji psychicznych u dzieci w wieku przedszkolnym. Master's thesis written under the direction of prof. dr. hab Stanisław 
Criteria for the selection of the examined children according to the level of functioning:

- age of children 4-7 years (data taken from children's documentation);

- ability to communicate verbally (in words or simple sentences) or to use non-verbal communication (gestures, facial expressions) (data taken from the child's records);

- level of mental development: mild to moderate intellectual disability (data taken from the child's records);

- diagnosis of the child: Down syndrome (data taken from the child's records: medical certificates, certificates from psychological-educational counselling centres);

- children attended specialist classes within the framework of Early Intervention and Development Assistance (Wrocław Model of Improvement Program).

For 9 months I observed 15 children with Down syndrome (selected according to the above criteria) in situations of casual play, guided play and targeted activities. The observations were recorded

Mihilewicz, University of Wrocław, Wrocław 2009 (the aim of the research was to show the possibilities and limitations of applying selected therapeutic methods in the work with pre-school children with impaired mental functions. In W. Sherborne's Developing Movement Method, the observation of a peer, who was also taking part in the activity, was encouraging and mobilizing for some children, the information carrier in this method was movement, and words were a secondary element, so the method was not burdened with language barriers, body language became universal, accessible to all and understandable (this was an opportunity especially for children with speech disorders, who did not have to use verbal language, but an easy and expressive body language). In the Polysensory Stimulation Method according to the Seasons of the Year, J. Kielin's Morning Circle, children learned about their surroundings on concrete and visual material (they could touch, smell, taste, see). The research led to the following conclusions: It must be said that children became more open, they played more in the group, they could focus on a specific activity, when playing they started to comment on what they were doing, this was especially visible in children with speech disorders. Their words may be unclear, specific, characteristic of the child, but express their emotions and needs. Children started to initiate contacts, involve third parties, encourage them with messages - play with us (to the volunteers who visited the group), children became creators and not just passive participants. 
on disordered sociograms, which are used for small groups. During the construction of the sociograms, I placed child X, whom I was observing at that moment, in the middle of the sheet of paper. Then I drew symbols of people who were chosen, disregarded or rejected by child $X$ and vice versa, people who chose, disregarded or rejected child $X$ when it took the initiative. The analysis of this kind of data allowed to identify those who were more popular, who receive the most positive and the least negative choices, those who were rejected (the most negative choices), disregarded (the least positive choices and the least negative choices). The records revealed the criteria used to select the children in the group. For example, often during casual play children without disabilities did not play or played briefly with children with Down syndrome because of the latter's impaired communication skills. Limited development of motor skills and coordination also made it difficult to play together. Children with Down syndrome, on the other hand, often did not understand the rules of the proposed games; they stood beside.

During the games organized by the teacher, they withdrew from the tasks that required a longer concentration span, physical activity (i.e. poor elements of their development). Also activities conducted with the use of verbal methods and concerning abstract topics caused their withdrawal. If the task in a team or in a pair was above the developmental capabilities of a child with Down syndrome, then often the child made it difficult for the child without disabilities to complete the task by accosting him or her, snorting, or taking away the tools needed to complete the task.

Observation in task situations could help to make the teacher and educator, as well as group members, aware that each task requires different skills and that not everyone was able to meet the requirements. This induced a way of thinking about children with Down syndrome - as a group of children with a specific developmental path.

The following research problems determining particular research stages were formulated:

The problem of the first stage (when observations recorded in sociograms were conducted): 
Is the role of preschool education in supporting the social development of children with Down syndrome noticeable?

Questions posed in the first stage of the research:

1.1. Does the psychosocial development of children with Down syndrome enable them to participate in tasks performed in their age group?

1.2. How does a child with Down syndrome experience contact with his or her peers?

1.3. How do healthy children react to the behaviour of their peers with disabilities?

Problems of the second stage:

What areas of social development can be developed in children with Down syndrome using individual therapeutic programs with elements of alternative and supportive communication methods? ${ }^{59}$

Questions posed in the second stage of the research:

2.1. Is it possible to teach a child with Down syndrome basic self-service activities or to improve the level of performance, and to what extent?

2.2. Is it possible to teach a child with Down syndrome to communicate, and to what extent?

2.3. Does playing together with peers create opportunities for the physical development of children with Down syndrome and to what extent?

2.4. Are playful and task-based situations an opportunity for children with Down syndrome to develop the ability to recognize and express their emotions correctly?

The diagnosis of psychosocial development of children was also based on the analysis of documentation, as another source of data collection, i.e.:

- decisions from psychological-educational counselling centres on the need for special education,

59 The applied therapeutic programs using elements of alternative and supportive communication methods constitute a separate issue and do not concern the presented topic. 
- the individual educational and therapeutic program from $2010 / 2011$ preceding the year of the experimental procedure,

- the journal of remedial and educational activities conducted by the teacher,

- a journal of observations of the behaviour of children with Down syndrome in situations of free play, guided play and organized activities prepared in the form of sociograms,

- interviews conducted with parents, teachers and educators dealing with the child.

The tools for diagnosing psychosocial development were P-PAC and PAC-1 developed by H.C. Gunzburg. The abbreviation PAC comes from the English name for the method: Progress Assesment Chart, which means evaluation of progress in social development. In the Polish version it is known as P-PAC, PAC-1 and PAC-2.60 I have diagnosed the social development of children at the beginning of the study (pretest) and at the end (after 9 months).

\section{Analysis and interpretation of test results}

I divided the image of progress in the social development of children into three levels:

- children with very visible progress in all areas (8 children/15 children),

- children with progress visible in all or some areas (clear uneven development of areas; 4 children/15 children),

- children with poorly visible progress in all areas (3 children/15 children).

60 T. Witkowski, Metody PAC i PAS w społecznej rewalidacji upośledzonych umystowo, Centralny Ośrodek Metodyczny Poradnictwa Wychowawczo-Zawodowego Ministerstwa Edukacji Narodowej, Warszawa 1988, p. 3.

61 All diagrams of progress in social development, including tables, are included in the post-doctoral monograph by A. Jędrzejowska, Wspomaganie rozwoju społecznego dzieci z zespołem Downa w przedszkolnej grupie rówieśniczej, Wydawnictwo Atut, Wrocław 2017. 
During the observation, I focused on the possibilities and limitations of developing children's social competences. In the sphere of socialization, different levels of functioning could be observed. The ability to focus on the partner was common for all children. Children reached out their hands towards the other person when they wanted to draw attention to something or to themselves; they smiled. They reacted with mimicry adequate to the observed, experienced event (emotionally clear, e.g. joyful, sad). The children waved their hands, in response, to say goodbye and hello. Parallel forms of play dominated their playful activity; alongside other children, without interaction. They often moved away from the group and organized individual games, e.g. in the kitchen corner or the book corner. There were also children who stood next to other children and just watched. Association games appeared (with external support) when children played together with other children, but without taking on tasks. The expectation of being praised for good behaviour was common to all children. The majority of children showed satisfaction and animation when hearing music (singing and dancing), some imitated the gestures of their peers or the teacher, accompanying the music, and movement games, others sang with their own vocalizations or single syllables. All of the children took part in a simple ball game (alternate rolling). Board games, e.g. ludo caught their attention only for a short period of time, and pawns were rather used for manipulative games.

In terms of communication: I made eye contact with all the children, which was also a communication channel (all the children communicated their needs and emotions by looking). Almost all of them used an alternate, consonant mimic dialogue. Children were able to share a common field of attention, though at a different time. All children used their own vocalizations. The verbal channel (single words) determined greater openness to interactions with peers in 5/15 children. All children, when hearing their name, reacted with animation, using specific reactions depending on their psychophysical abilities: they repeated their name, pointed at themselves, smiled, directed their eyes towards the person calling them. 
Most of them were able to ask for a certain activity (e.g. jumping on a ball), ask for things, e.g. a toy that was located in a higher place (some used a pointing gesture, some said "give", and some children only directed their gaze at the object they wanted) or used a gesture. They did not use the verbal question: why? If they did not understand, they would usually communicate with an enquiring look. They did not understand the relations between time and space. While listening to longer and more varied stories, they quickly got distracted; they needed pictures to keep focusing on the story, to understand it, and then to remember it. Children searched for the source of sounds, some of them made attempts to recognize and imitate it (e.g. animal sounds).

During guided activities, most of the children showed an understanding of simple instructions, but they exercised them in a selective manner. Children got involved when looking at children's books with their peers or teachers; they used numerous vocalizations and communicated with mimicking when looking at new pictures. They reacted more lively to familiar images (e.g. animals).

Manual skills and dexterity were underdeveloped. Children were reluctant to reach for crayons (drawing at the stage of scribbling). They preferred painting with paints on large sheets of paper. They needed much more time and attempts to perform fine motor skills tasks than their peers.

Spontaneous activity was dominated by schematic playing with objects, playing with the same car, the same doll, looking at the same book. Half of the children were diagnosed with right hand domination. Also half of the children distinguished red, green, yellow, blue, white, black. All the children had a developed concept of object constancy. Despite difficulties with fine motor skills, they made attempts to cut with scissors, wind thread on a spool. Children pointed to their own body parts and that of others (6/15 children required a visual hint). They had difficulty with simple classification of objects, e.g. based on whom they belonged to: mine - not mine, a friend's, the teacher's (sometimes they took other children's private toys or a sandwich/piece of meat from another plate and 
resisted when their peers tried to take their property back). The children divided the objects according to their characteristics: tasty not tasty, nice - not nice, i.e. based on their sensory experiences (taste, smell, touch).

In free play, children with low social and cognitive skills often experienced rejection, disregard or aroused controversy. The level of social (also communication) competence was particularly evident in play, as children with Down syndrome often did not understand the rules of play proposed by their non-disabled peers. Also, the limited development of motor skills and coordination hindered play together. A. Maciarz ${ }^{62}$ emphasizes that the mastery of various types of social skills is conditioned by the development of motor, emotional and motivational and intellectual dispositions in children. In task situations, delayed psychomotor development did not allow for full participation in the activities envisaged by the program for the whole group. Disturbances of mental processes such as memory, thinking, association, speech had a decisive influence on the level of involvement. It was noticeable that children had difficulties in understanding the requirements formulated exclusively by means of verbal communication. Children who understood the tasks had difficulties with their realization due to delayed motor development. Observing the emotional reactions of children in these situations brought to mind a comparison with the emotional reactions of a person who had just missed his/her bus: regret, frustration, anger, depression, submission, withdrawal. Such situations occurred several times a day in the case of each of the 15 children. This was transferred to the experience of contact with peers. If speech (receptive and expressive function), motor development, reaction time, cognitive abilities were developed enough to allow children to participate in games proposed by their peers, then children with Down syndrome were attractive play partners. Otherwise, they looked for their own safe niche to play together.

62 A. Maciarz, Rewalidacja społeczna dzieci, Wyższa Szkoła Pedagogiczna, Zielona Góra 1981, p. 23. 


\section{Conclusions}

Kindergarten is a time of transition from alienation to participation in a peer group. Each child needs the right conditions to move away from oneself to the Other, regardless of their health. Especially in a peer group, children can develop empathy, the ability to interact with others, the ability to share their own things, as well as their experiences, and the ability to react to events in their peer's life. These components of social competence have been particularly active in children with Down syndrome compared to other children with disorders. The children presented an attitude of concern for someone else's suffering; they often recreated the event that caused their peer to suffer, such as a fall or an injured knee, or grasped their own head when their peer had a headache. The children pointed out, to the teacher or other children, a friend who, for various reasons, experienced some kind of suffering and tried to explain what happened (using gestures, vocals, words). This became the foundation for building a bond that was formed between the children. It was strengthened through play, and children with Down syndrome played together in the free activities. Most often these included different theatrical forms (short scenes with dressing up children had access to a suitcase with different clothes in the theatre corner), puppet theatres, shadow theatres. Their psycho-physical abilities did not limit their participation in these forms of play. They experienced acceptance from each other, which further deepened openness and trust between them. Their sense of subjectivity was particularly strengthened during this kind of play. Rejected in play by children without disabilities, they regained their sense of dignity and value in mutual reception, watching, applauding during roleplaying or simulation. During these activities, the children were free to choose, make conscious decisions and deliberately direct their actions. This was also associated with a sense of causality, i.e. influence on the course of events (when they were actor-directors). Children "on stage" also experienced a sense of responsibility for their actions, as well as a sense of being equal (not worse) in contact with 
another person. The alternation of the actor and then the viewer gave the opportunity to shape the skills of alternate listening and being listened to in everyday dialogue, not only during the play. A group of children with Down syndrome began to function within a group which presented patterns of normal social behaviour. The everyday experience of the quality of interaction between these children led to the conclusion that, in addition to social development, children had a chance for a happy personal development. A fundamental task for the organizers of preschool education is to build an environment in which children with disabilities are surrounded by peers similar to them (in different ways) who are more understandable, more like themselves, less different. The idea of mutual similarity brings the children closer to each other, protects them from loneliness. A bond based on dialogue that is understandable to the children provides a mechanism that opens the opportunities for the development of social competences in children.

\section{References}

Andrzejewska J., Zróżnicowanie modeli edukacyjnych w przedszkolu a funkcjonowanie psychospoteczne dzieci, Wydawnictwo Uniwersytetu Marii Curie-Skłodowskiej, Lublin 2013.

Armstrong M., Zarządzanie zasobami ludzkimi, Oficyna Ekonomiczna, Kraków 2002.

Baczała D., Metoda Knillów a teoria osobowości Kurta Goldsteina (studium indywidualnego przypadku), [in:] Z. Gajdzica (ed.), Wspólne i swoiste zagadnienia edukacji i rehabilitacji osób z upośledzeniem umystowym, Wyd. Humanista, Sosnowiec 2008.

Bartosik B., Sadowska L., Kreft A., Postęp w rozwoju spotecznym matych dzieci z zespotem Downa poddanych terapii wedtug Wrocławskiego Modelu Usprawniania (WMU), [in:] J. Patkiewicz (ed.), Wspomaganie rozwoju dzieci z trudnościami w uczeniu się, Polskie Towarzystwo Walki z Kalectwem, Wrocław 2004.

Bartosik B., Sadowska L., Choińska A.M., Dojrzałość społeczna dzieci z zespotem Downa rehabilitowanych zgodnie z zasadami Wroctawskiego Modelu Usprawniania w środowisku rodzinnym, [in:] J. Patkiewicz (ed.), Zespót Downa - postępy w leczeniu, rehabilitacji i edukacji, Polskie Towarzystwo Walki z Kalectwem, Wrocław 2008.

Bee H., Psychologia rozwoju człowieka, Wydawnictwo Zysk i S-ka, Poznań 2004.

Białas A., Rodzina a problemy rozwoju, wychowania i socjalizacji dzieci i młodzieży niepetnosprawnej, [in:] J. Patkiewicz (ed.), Udziat rodziny w kompleksowej rehabilitacji 
i życiu dzieci i młodzieży niepetnosprawnej, Polskie Towarzystwo Walki z Kalectwem, Wrocław 1999.

Birch A., Malim T., transl. by J. Łuczyński, M. Olejnik, Psychologia rozwojowa w zarysie. Od niemowlęctwa do dorostości, Wydawnictwo Naukowe PWN, Warszawa 1995.

Borecka I., Drama w programach edukacyjnych, wychowawczych i terapeutycznych, [in:] I. Borecka, M. Widerowska i in., Drama i arteterapia w szkole. Programy $i$ scenariusze zajęć, Wydawnictwo Państwowej Wyższej Szkoły Zawodowej im. Angelusa Silesiusa, Wałbrzych 2005.

Brown S., Vaughan Ch., Play: How It Shapes the Brain, Opens the Imagination, and Invigorates the Soul, Nowy Jork, Penguin Group, 2009.

Brzezińska A.I., Mielcarek M., Ratajczyk A., Mali aktorzy na scenie życia, czyli o rozwoju kompetencji społecznych w okresie dzieciństwa, Mazowiecki Kwartalnik Edukacyjny „Meritum” 2014, no. 2(33), A.I. Brzezińska, M. Bątkowski et al., O roli zabawy w przygotowaniu dziecka do dorosłego życia. Wychowanie w Przedszkolu, 2011, no. 10.

Brzezińska A.I., Socjometria, [in:] J.M. Brzeziński (ed.), Metodologia badań społecznych. Wybór tekstów, Wydawnictwo Zysk i S-ka, Poznań 2011.

Cunningham C., Dzieci z zespołem Downa. Poradnik dla rodziców, WSiP, Warszawa 1992.

Czerepaniak-Walczak M., Między dostosowaniem a zmiana, Wydawnictwo Naukowe, US, Szczecin 1995.

Guzy-Steinke H., Wilk T., Uczeń $i$ teatr. Realia a poszukiwania możliwości realizacji edukacji teatralnej w szkole, Wydawnictwo Edukacyjne „Akapit”, Torun 2009.

Hall C.S., Lindzey G., Cambell G.B., Teorie osobowości, PWN, Warszawa 2004.

Jędrzejowska A., Wspomaganie rozwoju społecznego dzieci z zespołem Downa w przedszkolnej grupie rówieśniczej, Wydawnictwo Atut, Wrocław 2017.

Kaczan T., Wpływ wczesnej rehabilitacji mowy na rozwój umiejętności komunikacyjnych $i$ jezykowych u dzieci $z \mathrm{ZD}$. A doctoral thesis written under the direction of prof. dr hab. S. Maria Pecyna, Wyższa Szkoła Pedagogiki Specjalnej, Warszawa 2001.

Kaszlińska K., Diagnozowanie kompetencji społecznej dzieci przedszkolnych - możliwości i ograniczenia, „Przegląd Pedagogiczny” 2015, no. 1.

Koszewska K., Co to sq kompetencje społeczne?, Mazowiecki Kwartalnik Edukacyjny "Meritum", 2014, no. 2(33).

Kowalik S., Psychologia niepetnosprawności umystowej Kowalik S., Psychologia niepetnosprawności umystowej, [in:] H. Sęk (ed.), Psychologia kliniczna, Vol. 2, Wyd. Naukowe PWN, Warszawa 2005.

Lubowiecka J., Kompetencje spoteczne w sytuacjach edukacyjnych w przedszkolu, [in:] H. Sowińska (ed.), Dziecko w szkolnej rzeczywistości. Założony z rzeczywisty obraz edukacji elementarnej, Wydawnictwo UAM, Poznań 2011.

Maciarz A., Rewalidacja społeczna dzieci, Wyższa Szkoła Pedagogiczna, Zielona Góra 1981. 
Miśkowiec E., Ksztattowanie umiejętności kontaktów społecznych dziecka w rodzinie i przedszkolu, „Edukacja Elementarna w Teorii i Praktyce” 2006, no 25/3.

Morreale S.P., Spitzberg B.H., Barge J.K., Komunikacja między ludźmi. Motywacja, wiedza i umiejętności, przeł. D. Kobylińska, P. Izdebski, A. Jaworska, Warszawa 2007.

Olechnowicz H., Terapia dzieci z niepetnosprawnościa intelektualna, Wydawnictwo Naukowe PWN, Warszawa 2010.

Plummer M., Jak ksztattować umiejętności spoteczne. Gry i zabawy grupowe dla dzieci od lat pięciu do jedenastu, Wydawnictwo Fraszka Edukacyjna, Warszawa 2010.

Sadowska L., Bartosik B., Uspotecznianie dzieci z zespotem Downa jako proces pokonywania barier społecznych, [in:] J. Patkiewicz (ed.), Problemy barier rozwoju dzieci i młodzieży niepetnosprawnej, Polskie Towarzystwo Walki z Kalectwem, Wrocław 2004.

Sobolewska A., Cela, Wydawnictwo W.A.B., Warszawa 2002.

Taraszkiewicz M., Jak uczyć lepiej - czyli refleksyjny praktyk w działaniu, Wydawnictwa CODN, Warszawa, 2000.

Tarnowski J., Jak wychowywać?, Wydawnictwo ATK, Warszawa 1993.

Twardowski A., Rola petnosprawnych rówieśników w procesie wspomagania rozwoju dzieci niepetnosprawnych, [in:] W. Dykcik, A. Twardowski (ed.), Wspomaganie rozwoju i rehabilitacja dzieci z genetycznie uwarunkowanymi zespotami zaburzeń, Wyd. Naukowe Polskiego Towarzystwa Pedagogicznego, Poznań 2004.

Tylewska-Nowak B., Wiek przedszkolny - pomiędzy wyobcowaniem a grupa rówieśnicza, [in:] H. Kubiak, A. Jakoniuk-Diallo (ed.), Cztowiek niepetnosprawny w otoczeniu spotecznym, Wydawnictwo Difin SA, Warszawa 2011.

Włoch A., Maćkowiak K., Pedagogiczne aspekty procesu kreowania postaci scenicznej w teatrze, Wydawnictwo Uniwersytetu Opolskiego, Opole 2016.

Wygotski L.S., Wybrane prace psychologiczne, PWN, Warszawa 1971.

Zausmer E., Zabawy i umiejętności manualne, [in:] S.M. Pueschel (ed.), Ku lepszej przysztości. Zespót Downa. Przewodnik dla rodziców i opiekunów, Wydawnictwo Replika, Zakrzewo 2009.

Żyta A., Życie z zespołem Downa. Narracje biograficzne rodziców, rodzeństwa i dorostych osób z zespołem Downa, Oficyna Wydawnicza „Impuls”, Kraków 2011. 